\title{
APPLICATION OF ANALYTICAL METHODS FOR PREDICTING THE STRUCTURES OF STEEL PHASE TRANSFORMATIONS IN WELDED JOINTS
}

\author{
Wiesława Piekarska, Dorota Goszczyńska, Zbigniew Saternus \\ Institute of Mechanics and Machine Design Foundations, Częstochowa University of Technology \\ Częstochowa, Poland \\ w.piekarska@imipkm.pcz.pl,d.goszczynska@imipkm.pcz.pl,z.saternus@imipkm.pcz.pl
}

\begin{abstract}
The paper presents the feasibility the prediction of phase structures of the medium carbon S355 steel under the transformations running in welding process by using analytical methods. The relationships proposed here allow to specify start and finish temperatures of phase transformations in the case of formation of bainite, ferrite, pearlite and martensite structures at various cooling rates $\mathrm{v}_{8 / 5}\left(\mathrm{t}_{8 / 5}\right)$ as well. Continuous-Cooling-Transformation (CCT) diagram and volumetric fractions of each steel phases possible to occur are determined in function of cooling rates. Analytically obtained values are compared with results obtained by dilatometric research. Correctness of applied analytical methods in this field has been verified when the structure compositions formed in the heat affected zone (HAZ) of electric arc butt-welded sheets made of the S355 steel were predicted.
\end{abstract}

Keywords: phase transformations, phase volumetric fraction, heat affected zone, analytical methods, butt-welded joint

\section{Introduction}

Various temperatures and temperature gradients occurring during welding contribute to the changes in thermophysical and mechanical properties of material. Particularly different material properties occur in heat affected zone (HAZ), where a large variety of structures occurs conditioned by thermal cycles as a result of phase transformations in a solid state. Important in terms of load capacity of welded constructions, experimental methods for the analysis and prediction of structural composition of HAZ are time-consuming, require a large financial outlay and specialized equipment. Therefore, analytical methods are still developed and improved [1-10].

Analytical models concern prediction of HAZ structure on the basis of chemical composition of steel, elaboration of simplified CCT diagrams and estimation of mechanical properties of HAZ of welded joints [2, 7, 9, 11, 12]. Analytical formulas are determined using the statistical analysis of results of experimental studies 
for a certain group of materials. Most often averaged values are assumed, which reduces the accuracy of models in the analysis of particular materials and specific welding technology. Despite these limitations, analytical formulas are invaluable in assessing the weldability and welding conditions, largely eliminating costly and labor-intensive technology research. Particularly, the use of the combined analytical methods and results of numerical analysis seems to be very attractive [11,13-17]. Results obtained by analytical methods are often used in the initial analysis of material properties, preceding experimental studies and during the development of mathematical models. They also allow for the reduction of costs and speedup of the development of welding technology.

The analysis of phase transformations in a solid state during welding of S355 steel is presented in this paper in terms of the use of analytical methods. Corresponding to cooling rates $\mathbf{v}_{8 / 5}$ start and finish temperatures of phase transformations of bainite, ferrite, pearlite and martensite are determined on the basis of given empirical relations. A CCT diagram is estimated. Phase fractions of each structure constituent are obtained depending on established cooling rates. Values obtained analytically are compared with results obtained by dilatometric research. Results of the prediction of the structure composition obtained using analytical methods are presented for electric arc butt-welded steel sheets.

\section{Experiment. CCT diagram of S355 steel}

Dilatometric research on high strength steel was performed in order to verify the CCT diagram of austenite transformation obtained by using analytical relationships and to evaluate their usefulness. Executed dilatometric tests allowed to obtain experimental CCT diagram and corresponding phase volumetric fractions of each structure constituent which is formed during cooling from the decomposition of austenite phase.

Table 1

Chemical composition of S355 steel in \%

\begin{tabular}{|c|c|c|c|c|c|c|c|c|}
\hline Steel & $\mathrm{C}$ & $\mathrm{Mn}$ & $\mathrm{Si}$ & $\mathrm{P}$ & $\mathrm{S}$ & $\mathrm{Al}$ & $\mathrm{Cr}$ & $\mathrm{Ni}$ \\
\hline $\mathrm{S} 355$ & 0.19 & 1.05 & 0.20 & 0.028 & 0.02 & 0.006 & 0.08 & 0.11 \\
\hline
\end{tabular}

Dilatometric research was performed with DIL805 Bahr Thermoanalyse GmbH dilatometer for $\mathrm{S} 355$ steel with chemical composition shown in Table 1. Austenitization temperature $T_{A}=1200^{\circ} \mathrm{C}$ and heating rate $100 \mathrm{~K} / \mathrm{s}$ were assumed in dilatometric research as well as different cooling rates simulating thermal cycles in welding. Dilatometric and microstructural analysis supported by microhardness measurement were applied to evaluate dilatometric samples. Both CCT diagrams of S355 steel, obtained in dilatometric research for different cooling rates $\mathrm{v}_{8 / 5}$, where $\mathrm{v}_{8 / 5}=(800 \div 500) / \mathrm{t}_{8 / 5}$ and $\mathrm{t}_{8 / 5}$ is a cooling time in the range of $800 \div 500^{\circ} \mathrm{C}$ and final 
volumetric fractions of phases (final structure composition of analyzed steel) for specified cooling rates are shown in Figure 1 [15].

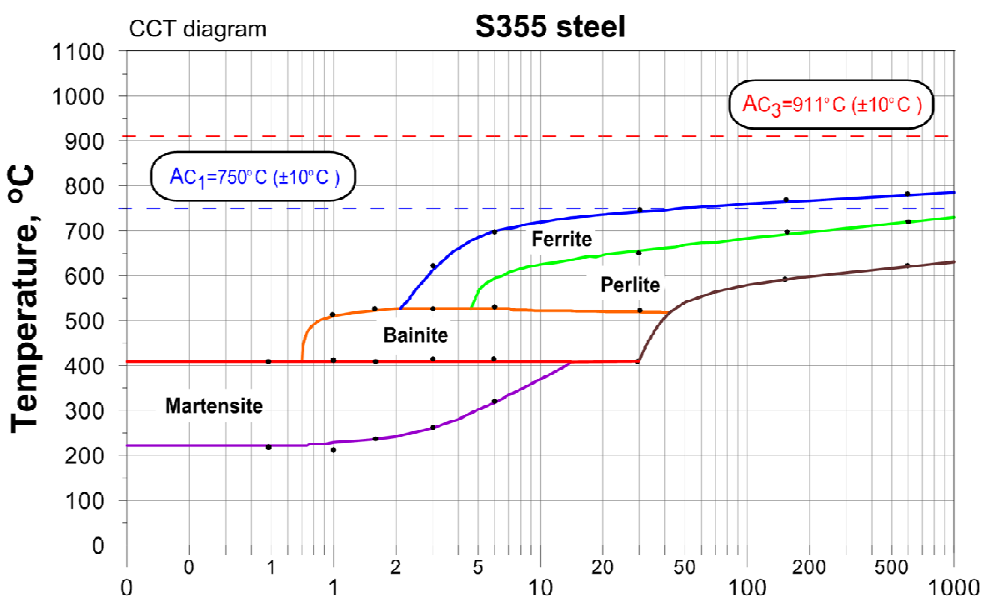

Time $t_{8 / 5}, s$

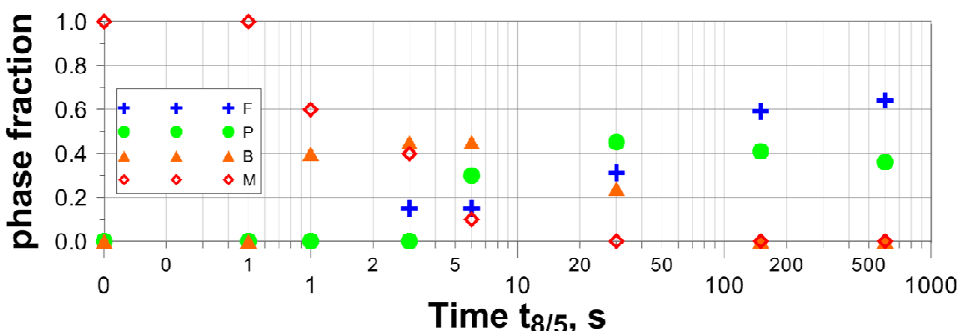

Fig. 1. CCT diagram and phase fractions of S355 steel [15]

\section{Analytical methods of phase transformations analysis. Analytical CCT diagrams}

Analytical models created on the basis of the composition of steel are used to predict the structure composition of HAZ, further to develop simplified CCT diagrams. For many years, analytical methods for the analysis of phase transformations in solid state are the subject of studies and improvement. Equations are obtained by the use of statistical analysis of results of experimental research performed for certain material groups. As a result, models developed by different authors are given, allowing the determination of characteristic quantities of austenite transformation. Different forms of the relationships shown in the literature give different results. These relationships concern the start and finish temperatures and times of phase transformations during heating and cooling, cooling rates as a function of the heat source power and critical cooling rates wherein hardening structures are present. Among the phenomenological formulas used in this field there are few others 
that additionally take into account the cumulative impact of carbon and alloying elements and few that additionally take into account the mutual influence of alloying elements $[2-4,7,11]$. Formulas used in the analysis of welding are presented in work [2]. Selected analytical dependencies presented in this paper refer to a group of weldable low carbon and high strength steels, including analyzed S355 steel. Symbols of chemical elements provided by all empirical formulas mean percentage of a given element, e.g. $\mathrm{C} \rightarrow \% \mathrm{C}$.

In this paper two analytical models are used to create an analytical CCT diagram with different approaches in determining the time of initiation of austenite transformation.

Start and finish temperatures of each phase transformation are determined for start and finish times of phase transformations estimated in relation to the chemical composition of the analyzed steel.

Time $t_{8 / 5}$ and start times of diffusive transformations as: bainite $t_{B}$, ferrite $t_{F}$ and perlite $t_{\mathrm{P}}$ are described by model I [3] and model II [2], expressed as follows:

Model I:

$$
\begin{gathered}
\ln \mathrm{t}_{\mathrm{B}}=-2.4+0.45 \sqrt{\mathrm{C}}+0.91 \mathrm{Mn}+0.37 \mathrm{Si}+0.57+0.91 \mathrm{Mo}+0.75 \mathrm{Ni} \\
\ln \mathrm{t}_{\mathrm{F}}=-3.3+6.9 \sqrt{\mathrm{C}}+2.0 \mathrm{Mn}+1.52 \mathrm{Cr}+2.66 \mathrm{Mo}-3.76 \mathrm{~V} \\
\ln \mathrm{t}_{\mathrm{P}}=0.825+1.64 \mathrm{Mn}+0.76 \mathrm{Si}+1.64 \mathrm{Cr}+2.17 \mathrm{Mo}+0.94 \mathrm{~N} \\
\ln \mathrm{t}_{\mathrm{k}}=-0.07+0.84 \mathrm{Mn}+1.40 \mathrm{Cr}+3.35 \sqrt{\mathrm{C}}
\end{gathered}
$$

where $t_{B}, t_{F}, t_{P}$ are start times of bainite, ferrite and pearlite transformations respectively, whereas $t_{k}$ is the finish time.

\section{Model II:}

$$
\begin{gathered}
\mathrm{t}_{\mathrm{B}}=-1.8+28.3 \mathrm{C}+17.1 \mathrm{Mn}-59.6 \mathrm{Si}-20 \mathrm{Cr}+13.2 \mathrm{Ni}+0.1 \mathrm{Mo}-5.3 \mathrm{~V} \\
+47.0 \mathrm{Nb}-289.6 \mathrm{C}^{2}-3.7 \mathrm{Mn}^{2}+65.4 \mathrm{Si}^{2}+38.6 \mathrm{Cr}^{2}-7.0 \mathrm{Ni}^{2}-21.0 \mathrm{Mo}^{2} \\
-9.8 \mathrm{CMn}-19.5 \mathrm{MnSi}+232.1 \mathrm{CSi} \\
\mathrm{t}_{\mathrm{F}}=10^{[5.8(\mathrm{C}+\mathrm{Si} / 291+\mathrm{Mn} / 14+\mathrm{Ni} / 67+\mathrm{Cr} / 16+\mathrm{Mo} / 6+\mathrm{V} / 425)-0.83]} \\
\mathrm{t}_{\mathrm{P}}=10^{[5.14(\mathrm{C}+\mathrm{Si} / 17+\mathrm{Mn} / 19+\mathrm{Ni} / 25+\mathrm{Cr} / 16+\mathrm{Mo} / 4+\mathrm{V} / 3)+0.06]}
\end{gathered}
$$

Time-dependent $\left(t=\mathrm{t}_{8 / 5}\right)$ start temperatures of the formation ferrite $F_{s}(t)$, bainite $B_{s}(t)$, pearlite $P_{s}(t)$ and the finish temperature of phase transformations $T_{k}(t)$ are determined by formulas $[3,4]$ in the following form: 


$$
\begin{gathered}
B_{s}(t)=T_{B 0}+\Delta T_{B} \operatorname{erf}\left[\left(\ln t-\ln t_{B}\right) K_{B}\right]+K_{B t} \ln t \rightarrow T_{B 0}=T_{B 0}\left(t_{B}\right)=M_{s} \\
F_{s}(t)=T_{F 0}+\Delta T_{F} \operatorname{erf}\left[\left(\ln t-\ln t_{F}\right) K_{F}\right]+K_{F t} \ln t \rightarrow T_{F 0}=B_{s}\left(t_{F}\right) \\
P_{s}(t)=T_{P 0}+\Delta T_{P} \operatorname{erf}\left[\left(\ln t-\ln t_{P}\right) K_{P}\right]+K_{P t} \ln t \rightarrow T_{P 0}=B_{s}\left(t_{P}\right) \\
T_{k}(t)=T_{k 0}+\Delta T_{k} \operatorname{erf}\left[\left(\ln t-\ln t_{k}\right) K_{k}\right]+K_{k t} \ln t \rightarrow T_{k 0}=T_{k 0}\left(t_{k}\right)=M_{s}
\end{gathered}
$$

values: $\Delta T_{B}, \Delta T_{B t}, \Delta T_{F}, \Delta T_{F t}, \Delta T_{P}, \Delta T_{P t}, \Delta T_{k}, \Delta T_{k t}$ depend on the chemical composition of examined steel:

$$
\begin{gathered}
\Delta T_{B}\left({ }^{\circ} \mathrm{C}\right)=172+88 \mathrm{C}-17 \mathrm{Mn}-34 \mathrm{Cr}-19 \mathrm{Ni} \\
K_{B}=0.68+1.2 \mathrm{C}+0.34 \mathrm{Si}-0.25 \mathrm{Cr}-0.17 \mathrm{Ni} \\
\Delta T_{F}\left({ }^{\circ} \mathrm{C}\right)=235-244 \mathrm{C}-60.6 \mathrm{Mn}-30 \mathrm{Si}-34 \mathrm{Cr}+45 \mathrm{Ni}+200 \mathrm{~V} \\
K_{F}=0.62+0.2 \mathrm{Cr}-0.45 \mathrm{Mo} \\
\Delta T_{P}\left({ }^{\circ} \mathrm{C}\right)=74+114 \mathrm{C}-32 \mathrm{Si}+94 \mathrm{Cr}-74 \sqrt{\mathrm{Ni}} \\
K_{P}=0.45+0.3 \mathrm{C}+0.9 \mathrm{Mo}-0.4 \mathrm{Ni} \\
\Delta T_{k}\left({ }^{\circ} \mathrm{C}\right)=101+200 \mathrm{C}-45.8 \mathrm{Si}-41.3 \mathrm{Cr}-350 \mathrm{~V}+670 \mathrm{Ti}-1100 \mathrm{Nb} \\
K_{k}=3.36+0.39 \mathrm{Mn}-0.32 \mathrm{Si}+0.31 \mathrm{Mo}+0.4 \mathrm{Ni}-0.94 \mathrm{~V}
\end{gathered}
$$

Coefficients: $\mathrm{K}_{\mathrm{Bt}}, \mathrm{K}_{\mathrm{Ft}}, \mathrm{K}_{\mathrm{Pt}}$ and $\mathrm{K}_{\mathrm{kt}}$ increase with the carbon content in the range: $\mathrm{K}_{\mathrm{Bt}}, \mathrm{K}_{\mathrm{Ft}}, \mathrm{K}_{\mathrm{kt}} \in[5 \div 15], \mathrm{K}_{\mathrm{Pt}} \in[3 \div 12]$.

Start temperatures of martensite transformation, according to model I $\left(\mathrm{M}_{\mathrm{sI}}\right)$ and model II $\left(\mathrm{M}_{\text {sII }}\right)$ are described respectively $[2,7]$ :

$$
\begin{gathered}
\mathrm{M}_{\mathrm{sI}}=506-37 \mathrm{C}-24.2 \mathrm{Mn}-14.4 \mathrm{Si}-14.7 \mathrm{Ni}+214 \mathrm{Nb} \\
\mathrm{M}_{\mathrm{sII}}=530-415 \mathrm{C}+90 \mathrm{C}^{2}-35 \mathrm{Mn}-30 \mathrm{Cr}-20 \mathrm{Ni}-15 \mathrm{~W}-10 \mathrm{Mo}
\end{gathered}
$$

Finish temperature of martensite transformation $\mathrm{M}_{\mathrm{f}}$ is defined by a widely used formula [2]:

$$
\begin{gathered}
\mathrm{M}_{\mathrm{f}}=381.76-252.44 \mathrm{C}-111.12 \mathrm{Mn}+54.538 \mathrm{Si}+114.17 \mathrm{Cr} \\
-23.779 \mathrm{Ni}-57.381 \mathrm{Mo}+215.7 \mathrm{~V}+945.4 \mathrm{Nb}+1821.7 \mathrm{Ti}-1746.5 \mathrm{~B}
\end{gathered}
$$

The CCT diagrams are obtained for the S355 steel in two ways - first one by using the formulas on the model I or the model II and the second one on the basis of dilatometric measurements as an experimental diagrams for any comparison are given in Figure 2. 


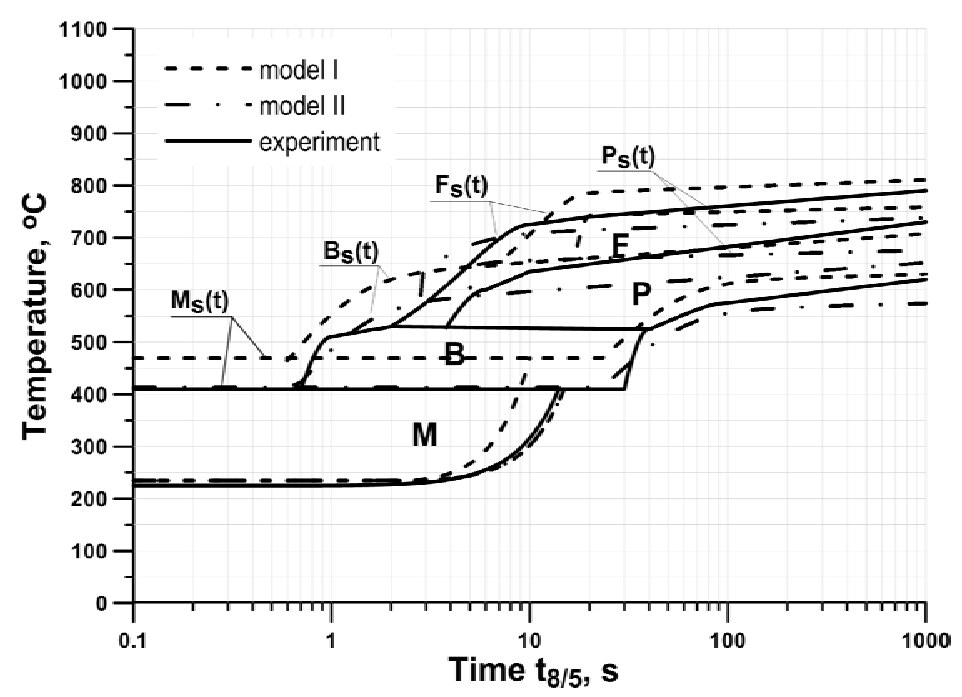

Fig. 2. CCT diagrams of S355 steel

Comparison of analytical CCT diagrams (model I and model II) with a diagram obtained by experimental research lead to the fact that empirical relationships properly reflect the decomposition of austenite phenomena. Model I a little more accurately reflects CCT diagram. Differences present in the position of certain curves, especially offset in the direction of the beginning of CCT diagram in the comparison with the real diagram may be due to the fact that experimental CCT diagram was obtained at the austenitizing temperature of $1200^{\circ} \mathrm{C}$, whereas presented models are developed for austenitizing temperature $1300^{\circ} \mathrm{C}$.

\section{Analytical methods for determining phase composition}

Depending on cooling rates the analytical model for determining phase composition is very useful in phase transformation analysis. Authors of $[2,3]$ presented equations which can be used to determine the structural composition of steel in ambient temperature obtained as a function of cooling time $t_{8 / 5}$. The volume fractions of particular phases, such as: ferrite-pearlite, bainite and martensite, as functions of time $t_{8 / 5}$ are described as follows:

$$
\begin{gathered}
\eta_{M}=0.5\left[1-\operatorname{erf} \frac{\left((\ln t)-\ln \Delta t_{F P}\right)}{\ln S_{F P}}\right] \\
\eta_{F P}=0.5\left[1-\operatorname{erf} \frac{\left((\ln t)-\ln \Delta t_{M}\right)}{\ln S_{M}}\right] \\
\eta_{B}=1-\eta_{M}-\eta_{F P}
\end{gathered}
$$


where:

$$
\begin{gathered}
\ln \Delta t_{F P}=0.85+7.43 \mathrm{C}+1.84 \mathrm{Mn}+0.55 \mathrm{Cr}+3.2 \mathrm{Mo}+0.95 \mathrm{Ni}-9.26 \mathrm{C}^{2} \\
\ln S_{F P}=1.42-1.6 \mathrm{C}+0.23 \mathrm{Mn}+0.42 \mathrm{Si}+0.22 \mathrm{Ni}+0.32 \mathrm{Mo} \\
\ln \Delta t_{M}=-1.49+13.6 \mathrm{C}+1.0 \mathrm{Mn}+0.33 \mathrm{Si}+0.48 \mathrm{Cr}+0.94 \mathrm{Mo}+0.87 \mathrm{Ni}-14.2 \mathrm{C}^{2} \\
\ln S_{M}=0.65-0.52 \mathrm{C}+0.23 \mathrm{Mn}+0.16 \mathrm{Cr}+0.18 \mathrm{Mo}
\end{gathered}
$$

In above formulas $\Delta t_{F P}, \Delta t_{M}$ mean the predicted cooling times from the start temperature of $800^{\circ} \mathrm{C}$ to obtain $50 \%$ fraction of ferrite-pearlite or martensite phase, where $t=\Delta \mathrm{t}_{8 / 5}$ is a cooling time in the temperature range $800 \div 500^{\circ} \mathrm{C}$.

Volumetric fractions of phases in the function of time $t_{8 / 5}$ are designated on the basis of equations (13)-(16). The distribution of phase fractions obtained on the way of dilatometric investigations with marked volumetric fractions is shown in Figure 3. From the comparison of presented distributions it can be seen that analytical models are suitable only for times $t_{8 / 5}$ above $2 \mathrm{~s}$ which correspond to the cooling rate $150^{\circ} \mathrm{C} / \mathrm{s}$. The highest differences in comparison with experimental data can be observed for low cooling times.

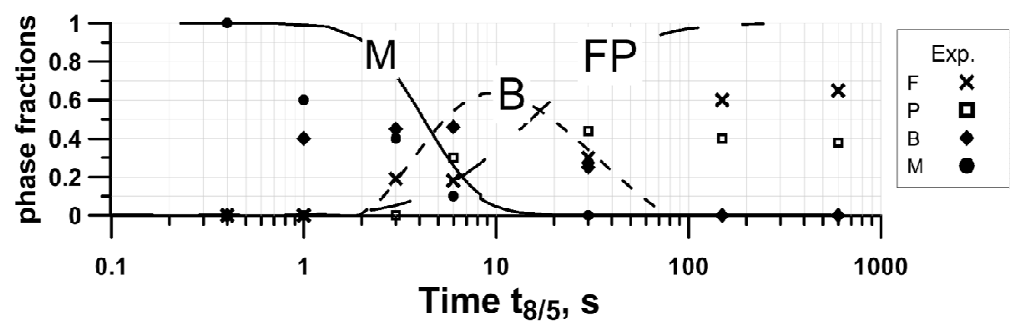

Fig. 3. Phase volumetric fractions of S355 steel

\section{Exemplary prediction of structural composition in butt-welded joint using analytical methods}

The electric arc butt-welding of S355 steel sheets of dimensions 150x30x3 mm is considered. Temperature field in welded joints is determined using Abaqus/FEA, an engineering software based on finite element method (FEM). The analysis of thermal phenomena is made on the basis of the solution of energy conservation equation together with Fourier law [18]. The temperature field expressed in the criterion of weighted residuals method is described by the following equation:

$$
\int_{V} \rho \frac{\partial U}{\partial t} \delta T d V+\int_{V} \frac{\partial \delta T}{\partial x_{\alpha}} \cdot\left(\lambda \frac{\partial T}{\partial x_{\alpha}}\right) d V=\int_{V} \delta T q_{V} d V+\int_{S} \delta T q_{S} d S
$$

where $\lambda$ is a thermal conductivity $[\mathrm{W} / \mathrm{mK}], U$ is the internal energy $[\mathrm{J} / \mathrm{kg}], q_{v}$ is the capacity of the laser beam power $\left[\mathrm{W} / \mathrm{m}^{3}\right], T=T\left(x_{\alpha}, t\right)$ is a temperature $[\mathrm{K}], q_{s}$ is a density of heat flux $\left[\mathrm{W} / \mathrm{m}^{2}\right], \delta T$ is a partial differential of $T$. 
Equation (17) is completed by the initial condition $t=0: T=T_{0}$, boundary conditions of Dirichlet, Neumann and Newton type with the heat loss due to convection and radiation:

$$
\begin{gathered}
\left.T\right|_{\Gamma}=\widetilde{T} \\
q_{S}=-\lambda \frac{\partial T}{\partial n}=-q(r, 0)+\alpha_{k}\left(\left.T\right|_{\Gamma}-T_{0}\right)+\varepsilon \sigma\left(\left.T\right|_{\Gamma}{ }^{4}-T_{0}^{4}\right)
\end{gathered}
$$

where $\alpha_{k}$ is convective coefficient (assumed as $\alpha_{k}=100 \mathrm{~W} /\left(\mathrm{m}^{2}{ }^{\circ} \mathrm{C}\right), \varepsilon$ is radiation) ( $\varepsilon=0.5), \sigma$ is Stefan-Boltzmann constant and $q(r, 0)$ is the heat flux towards the top surface of a welded workpiece, $T_{0}=20^{\circ} \mathrm{C}$ is an ambient temperature.

The analysis of the temperature field is performed in Lagrange coordinates, hence heat transfer equation (17) is considered without convection unit. Coordinates of the centre of the welding heat source are determined for each time step, depending on the assumed welding speed.

A movable welding source is implemented in Abaqus/FEA [18] using additional numerical DFLUX subroutine. Mathematical model of Goldak's volumetric heat source power distribution is used in the analysis [19]:

$$
\begin{gathered}
q_{f}(x, y, z)=\frac{6 \sqrt{3} f_{f} Q}{a b c_{f} \pi \sqrt{\pi}} \exp \left(-3 \frac{x^{2}}{a^{2}}\right) \exp \left(-3 \frac{y^{2}}{c_{f}^{2}}\right) \exp \left(-3 \frac{z^{2}}{b^{2}}\right) \\
q_{r}(x, y, z)=\frac{6 \sqrt{3} f_{f} Q}{a b c_{r} \pi \sqrt{\pi}} \exp \left(-3 \frac{x^{2}}{a^{2}}\right) \exp \left(-3 \frac{y^{2}}{c_{r}{ }^{2}}\right) \exp \left(-3 \frac{z^{2}}{b^{2}}\right) \\
q(x, y, z)=q_{f}(x, y, z)+q_{r}(x, y, z)
\end{gathered}
$$

where $a, b, c_{r}$ and $c_{f}$ are dimensions of semi-ellipsoid axes, $f_{f}$ and $f_{r}$ are values representing energy distribution in the front and in the back of the heat source, satisfying the condition: $f_{r}+f_{f}=2$.

Presented in Table 2, welding parameters are assumed in calculations of the temperature field.

Table 2

Welding parameters

\begin{tabular}{|c|c|c|c|c|c|c|c|c|c|c|c|}
\hline $\begin{array}{c}Q \\
{[\mathrm{~W}]}\end{array}$ & $\begin{array}{c}T_{0} \\
{\left[{ }^{\circ} \mathrm{C}\right]}\end{array}$ & $\begin{array}{c}v \\
{[\mathrm{~mm} / \mathrm{s}]}\end{array}$ & $\begin{array}{c}\lambda \\
{\left[\mathrm{W} / \mathrm{m}^{\circ}{ }^{\circ} \mathrm{C}\right]}\end{array}$ & $\begin{array}{c}c \\
{\left[\mathrm{~J} / \mathrm{kg}{ }^{\circ} \mathrm{C}\right]}\end{array}$ & $\begin{array}{c}\rho \\
{\left[\mathrm{kg} / \mathrm{m}^{3}\right]}\end{array}$ & $\begin{array}{c}a \\
{[\mathrm{~mm}]}\end{array}$ & $\begin{array}{c}b \\
{[\mathrm{~mm}]}\end{array}$ & $\begin{array}{c}c_{r} \\
{[\mathrm{~mm}]}\end{array}$ & $\begin{array}{c}c_{f} \\
{[\mathrm{~mm}]}\end{array}$ & $f_{r}$ & $f_{f}$ \\
\hline 2200 & 20 & 9 & 35 & 650 & 7760 & 50 & 0.5 & 3 & 7 & 1.4 & 0.6 \\
\hline
\end{tabular}


Numerical calculations of the temperature field are performed as a 3D task. The cross-section of the considered welded joint is presented in Figure 4, where analysed material points are marked. Temperature distributions in the central layer at different distances from the axis of the source are presented in Figure 5 where characteristic $t_{8 / 5}$ times are pointed out (Fig. 4). Points 1 and 2 that are marked in Figure 4 belong to the weld, while points 3 and 4 belong to the heat affected zone. On the basis of determined temperature distributions the analysis of phase transformations is performed. Results of the analysis for chosen points at various distances from the weld line are presented in the cross-section of the weld (points 1, 2, 3 and 4).

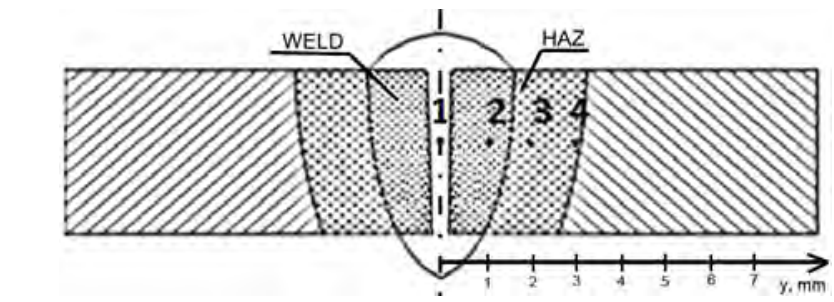

\begin{tabular}{|c|c|c|c|c|}
\hline Points & $\mathbf{1}$ & $\mathbf{2}$ & $\mathbf{3}$ & $\mathbf{4}$ \\
\hline Distance from the weld line $\mathbf{y}[\mathbf{m m}]$ & 0 & 1 & 2 & 3 \\
\hline Time $\mathbf{t}_{\mathbf{8} / \mathbf{5}}[\mathbf{s}]$ & 7 & 7.5 & 8 & 8.5 \\
\hline
\end{tabular}

Fig. 4. Welded joint - scheme of considered system

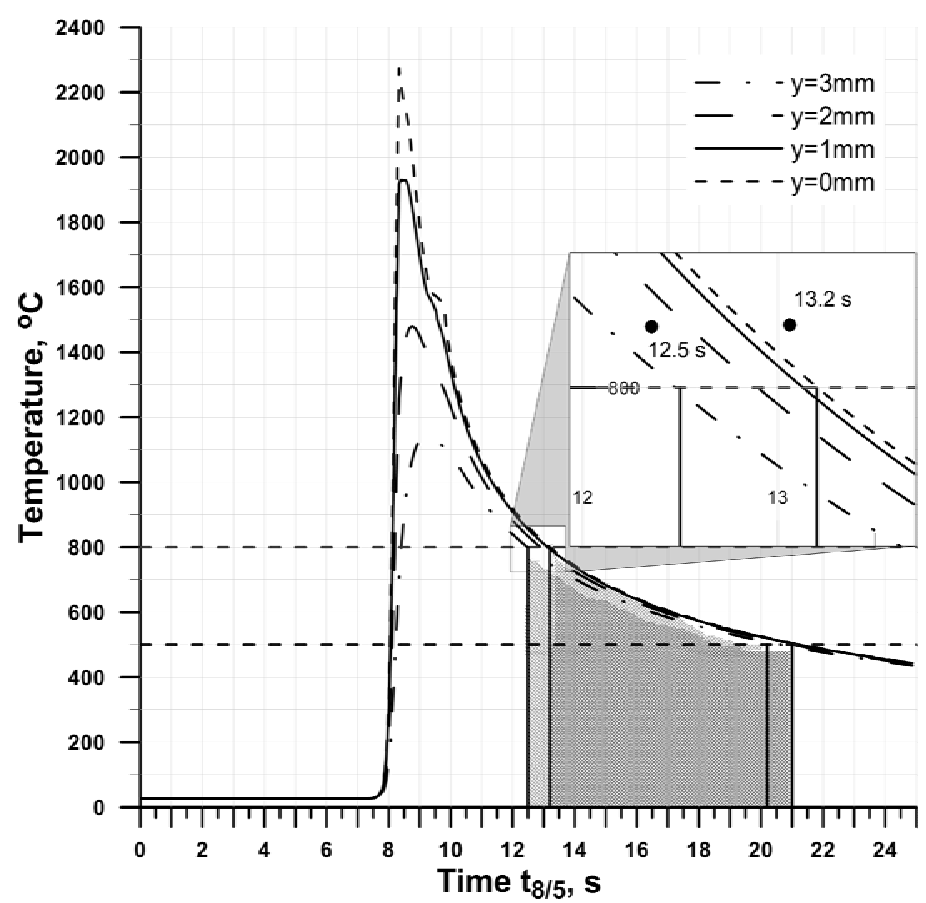

Fig. 5. Temperature distributions at different distances from the centre of the heat source 
The prediction of structural composition in the weld and HAZ is performed on the basis of calculated volumetric fractions of phases in a function of time $\Delta t_{8 / 5}$. The results of both the analytical prediction and the experimental results of investigations are shown in Figure 6. Distributions of diffusive phases of ferrite + pearlite exhibit great conformity with the experimental results. However, this conformity is not observed in the case when the composition of martensite and bainite is analyzed. Mathematical models of these phases' formations should be further analyzed and verified on the basis of experimental studies developed for considered group of steels.

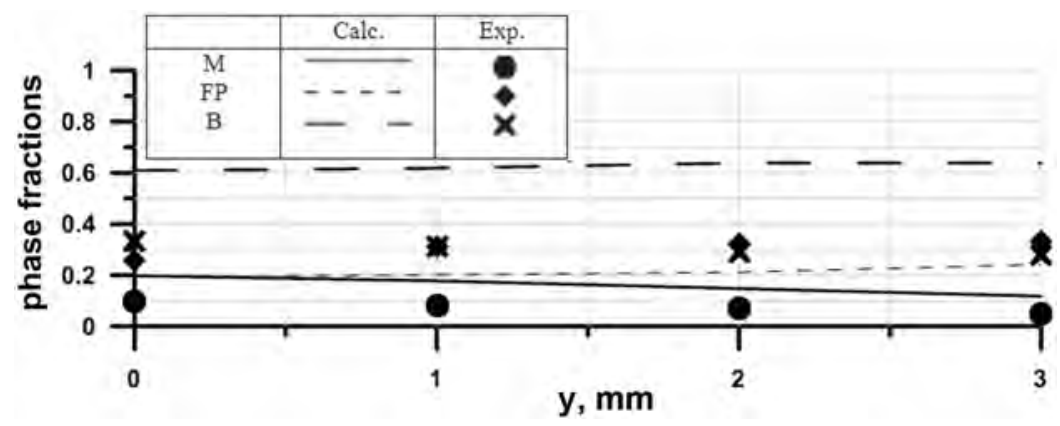

Fig. 6. Phase fractions in relation to the distance from the weld line

\section{Conclusions}

Analytical methods for the creation of simplified CCT diagrams and for the prediction of the structure in HAZ that are based on the chemical composition of analyzed steel are very useful. They can be used as a cheap tool for assessing microstructure of the weld and in consequence mechanical properties of welded joints. The accuracy of the assessment is a major problem. In this paper the usefulness of CCT diagrams and formed microstructure has been assessed.

Summarizing the results of analysis, it can be concluded that for steel research, analytical models with high accuracy can be used to develop CCT diagrams that are in a good agreement with experimental results. Presented empirical relations well reflect austenite decomposition phenomena. Existing differences are present due to the fact that experimental CCT diagram was obtained at the austenitizing temperature of $1200^{\circ} \mathrm{C}$, which is usually used in standard dilatometric tests. In contrast, presented mathematical models with the effect of cooling rate on temperatures of phase transformations taken into account are based on studies of phase transformations in steels heated to austenitizing temperature of $1300^{\circ} \mathrm{C}$. The aim of further research will be the development of mathematical models for the interpolation of CCT diagram and phase fractions from the temperature of $1300^{\circ} \mathrm{C}$ to $1200^{\circ} \mathrm{C}$.

Structure composition in the weld and HAZ can be predicted on the basis of analytical estimation of volumetric fractions of phases and CCT diagram. 
During the analysis of the comparison of calculated phase fractions with results of experimental research (Fig. 3) divergence in martensite and bainite phases are observed in the range of low times $t_{8 / 5}$ (high cooling rates). The comparison shows that presented analytical models are proper only for time $t_{8 / 5}$ above $2 \mathrm{~s}$, which responds to cooling rate $150^{\circ} \mathrm{C} / \mathrm{s}$. In this meaning, analytical methods can be used for the analysis of welding technology in the case where cooling rates, found in the range of $800 \div 500^{\circ} \mathrm{C}$, won't exceed $150^{\circ} \mathrm{C} / \mathrm{s}$. The presented example of the prediction of phase composition in welded joint confirms this tendency.

\section{References}

[1] Perret W., Schwenk C., Rethmeier M., Comparison of analytical and numerical welding temperature field calculation, Computational Materials Science 2010, 47, 1005-1015.

[2] Mikuła J., Analityczne metody oceny spawalności stali, Zeszyty Naukowe Mechanika nr 85, Politechnika Krakowska, Kraków 2001.

[3] Seyffarth P., Kasatkin O.G., Mathematisch-statistische Beschreibung der Austenitumwandlung in der Wärmeeinflußzone, Schweißtechnik 1979, 29, 117-119.

[4] Kasatkin O.G., Seyffart P., Interpolâcionnye modeli dlâ ocenki fazovogo sostava zony termičeskogo vliâniâ pri dugovoj svarke nizkolegirovannyh stalej, Avtomat. Svarka 1984, 1, 7-11.

[5] Makhnenko V.I., Saprygina G.U., Rol' matematiceskogo modelirovania v resenii problem svarki raznorodnyh stalej, Avtomat. Svarka 2002, 3, 18-28.

[6] Mittemeijer E.J., Sommer F., Solid state phase transformation kinetics: a modular transformation model, Z. Metallkd. 2002, 93, 352-360.

[7] Piekarska W., Analiza numeryczna zjawisk termomechanicznych procesu spawania laserowego. Pole temperatury, przemiany fazowe i naprężenia, seria Monografie nr 135, Wydawnictwo Politechniki Częstochowskiej, Częstochowa 2007.

[8] Tasak E., Metalurgia spawania, Wyd. JAK, Kraków 2008.

[9] Shen H., Shi Y., Yao Z., Hu J., An analytical model for estimating deformation in laser forming, Computational Materials Science 2006, 37, 593-598.

[10] Elmer J., Palmer T.A., Zhang W., Wood B., DebRoy T., Kinetic modeling of phase transformation occuring in the HAZ of C-Mn steel welds based on direct observations, Acta Materialia 2003, 51, 12, 3333-3349.

[11] Seyffart P., Kasatkin O.G., Rascentnye modeli dla ocenki mechaniceskich svojstv metalla ZTV pri svarke nizkoegirovannych stalej, Proc. Int. Conference Mechanical Modelling and Information Technologies in Welding and Related Processes, ed. V.I. Makhnenko, Katsiveli, Crimea, E.O. Paton Welding Inst. of NAS of Ukraine, Kiev 2002, 103-106.

[12] Zaczek Z., Ćwiek J., Prediction of HAZ hardness in welds of quenched and tempered HSLA steels, Welding Journal, res. supp. 1993, 1, 37-40.

[13] Winczek J., Rygał G., Modelling of a temporary temperature field during arc weld surfacing of steel elements taking into account heat of the weld, J. Appl. Math. Comput. Mech. 2015, 14(1), 111-120.

[14] Franco A., Romoli L., Musacchio A., Modelling for predicting seam geometry in laser beam welding of stainless steel, International Journal of Thermal Sciences 2014, 79, 194-205.

[15] Piekarska W., Kubiak M., Theoretical investigations into heat transfer in laser-welded steel sheets, J. Therm. Anal. Calorim. 2012, 110, 159-166. 
[16] Makhnenko V.I., Velikoivanenko E.A., Makhnenko O.V., Rozynka G.F., Pivtorak N.I., Issledovanie vlijanija fazovych prevrascenij na ostatocnye naprjazenija pri svarke kol'cevych stykov trub, Avtomat. Svarka 2000, 5, 3-8.

[17] Piekarska W., Bokota A., Modelirovanie ostatocnych naprjazenij pri lazernoj svarke, Avtomaticeskaja Svarka 2008, 6, 25-31.

[18] SIMULIA Dassault System, Abaqus theory manual, Version 6.7, 2007.

[19] Goldak J. A., Computational Welding Mechanics, Springer, New York 2005. 